\title{
Implementasi Pengamanan PGP pada Platform Zimbra Mail Server
}

\author{
Dandy Pramana Hostiadi ${ }^{1}$, Ida Bagus Suradarma ${ }^{2}$ \\ STMIK STIKOM Bali \\ Jl. Raya Puputan No. 86 Renon, Denpasar-Bali \\ 1dandypramanahostiadi97@gmail.com \\ 2suradarma@stikom-bali.ac.id
}

\begin{abstract}
Abstrak
Elektronik mail merupakan model komunikasi yang sifatnya fundamental di era globalisasi, terbukti pada setiap bentuk registrasi data atau informasi, membutuhkan adanya data email (surat elektronik). Perkembangan teknologi komunikasi khususnya penggunaan email, membawa pengaruh terhadap tindak penyalahgunaan email seperti adanya aktivitas pencurian akun dan pemalsuan email. Keamanan komunikasi pada mail server seperti mail server ZIMBRA sudah terimplementasi dengan baik, seperti penggunaan ss/ certificate, namun pengamanan tersebut masih standar. Isi email dapat terbaca dengan mudah (dalam teknik kriptografi dikatakan pembacaan plainteks) ketika user dan password telah diketahui oleh pihak ketiga maka. Metode pretty good privacy (PGP) diterapkan pada penelitian ini sebagai pengamanan komunikasi email, difokuskan pada isi email dengan mengenkripsi teks mail beserta attachment file. Mail engine yang digunakan yaitu Zimbra mail server. Hasil dari penelitian menunjukkan bahwa pengamanan PGP mampu mengamankan isi email baik teks maupun attachment, dengan perbedaan size file attachment lebih besar pada penggunaan PGP dan mengubah header mail dari mail standar.
\end{abstract}

Kata kunci: Email, Zimbra Mail Server, PGP, Enkripsi.

\begin{abstract}
Electronic mail is a communication model that is fundamental in the era of globalization. Proven on any form of registration data or information requires the presence of email address(electronic mail). The use of email itself cannot be separated from the abuse (such as stelling password and mail spoofing) from some parties so it needs security form in email communication. Communication security on mail server such as ZIMBRA mail server has been well-implemented, such as the use of ss/ certificate. But the security is still standard. So, when user and password have been found out by third party, email content will be read easily (in cryptography technique it is called plaintext reading). On research that was conducted with pretty good privacy (PGP) method email communication security was focused on the email content by encrypting mail text along with the attachment file. In a study conducted, using the mail engine Zimbra mail server. Result of research shows that PGP security is able to secure email content whether the text or the attachment, showing difference of attachment file size is bigger on PGP using and change mail header from the standard mail.
\end{abstract}

Keywords: Email, Zimbra Mail Server, PGP, Encryption.

\section{Pendahuluan}

Email merupakan bentuk komunikasi yang dikatakan bersifat fundamental di-era globalisasi. Hal ini terlihat bahwa saat ini hampir pemanfaatan komunikasi selalu mensyarakatkan pencantuman alamat email (electronic mail). Contohnya adalah pada registrasi sosial media dimana pada form registrasi mewajibkan mencantumkan alamat email. Komunikasi di beberapa perusahaan maupun pemerintahan dalam komunikasi jarak jauh lintas pulau maupun negara juga memerlukan alamat email. Jumlah organisasi yang tak terhitung jumlahnya di seluruh dunia terus mengubah metode mereka dalam hal komunikasi yang dulu menggunakan kertas (hardcopy) 
menjadi salah satu factor utama perubahan menuju basis komputerisasi (email) berdasarkan sistem untuk menyimpan data penting dan informasi. Hal ini dapat disimpulkan bahwa email (email) merupakan data / informasi primer bagi pelaku komunikasi di era global.

Seiring perkembangan penggunaan email sebagai bentuk komunikasi, tidak terlepas dari adanya pihak yang menyalahgunakan penggunaan email dan mengarah pada pelanggaran hukum. Seperti adanya penipuan dengan penggunaan account mail palsu atau adanya pencurian password dan pembajakan account email [1]. Secara teori pengamanan terhadap komunikasi perlu dilakukan. Mengamankan email adalah sesuatu yang harus dilakukan oleh pengguna sendiri, karena mereka adalah salah satu yang akan benar-benar menjadi tanggung jawab pengirim dan penerima pesan. Terdapat beberapa teknik pengamanan komunikasi dalam jaringan termasuk didalamnya adalah komunikasi email seperti teknik kriptografi, dengan algoritma yang berbeda [2]. Sebagai contoh adalah mail server Zimbra yang sudah menerapkan pengaman certificates ssl. Zimbra mail server sendiri merupakan mail engine yang sudah banyak digunakan di beberapa perusahaan dengan fitur yang fleksibel dan simple untuk digunakan serta bersifat open source [3]. Namun keamanan dengan certificate ssl belum menjamin sepenuhnya keamanan pada mail server. Seperti halnya pencurian account mail, ketika pihak yang tidak berkepentingan berhasil mendapatkan user mail dan password, maka dengan mudahnya membaca isi email dan mengetahui informasi yang sifatnya rahasia dalam email. Untuk mencegah hal tersebut maka keamanan komunikasi email perlu ditingkatkan dan salah satu caranya adalah dengan pengamanan PGP (Pretty Good Privacy). Dengan PGP pengamanan komunikasi email memfokuskan pada pengamanan isi email (mengantisipasi pembacaan isi mail secara mudah oleh pihak yang tidak berkepentingan) termasuk di dalamnya adalah file attachment. Pada Penelitian yang dilakukan, dimana mengimplementasikan pengamanan PGP pada Zimbra mail server akan melihat sejauh mana pengamanan yang dilakukan dengan melihat dari hasil PGP, analisa terhadap file attachment dan header email.

\section{Metodologi Penelitian}

Pada penelitian yang dilakukan alur metodologi penelitian digambarkan pada skema berikut :

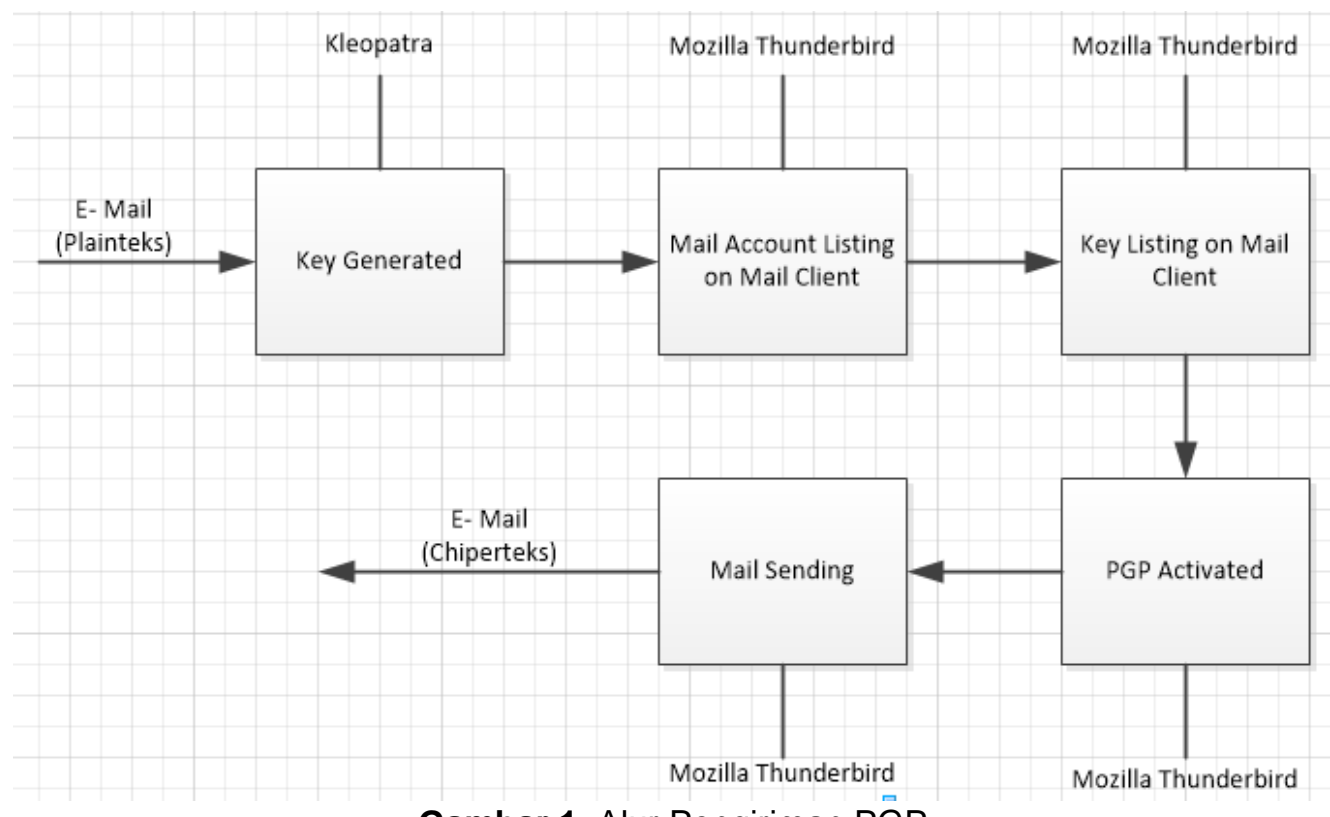

Gambar 1. Alur Pengiriman PGP

Dari gambar 1, secara garis besar, pengiriman PGP melalui beberapa tahap, yaitu :

a. Key Generated

Key Generated adalah tahapan dimana key PGP di buat dan nantinya digunakan dalam pengamanan pengiriman email. Key yang dihasilkan dalam pembuatan kunci, memiliki 
fitur untuk pembatasan waktu penggunaan, yang bertujuan untuk membatasi masa penggunaan key yang dibuat terhadap sesi pengiriman email. Setelah membuat kunci private diperlukan passphrase yang nantinya digunakan untuk mendekrip pesan saat mengirimkan dan di sisi penerima saat membaca pesan yang diterima. Kunci private yang telah dibuat harus dimiliki juga oleh penerima, dapat dilakukan dengan manual atau pengiriman konvensional ke penerima pesan. Perlu diingat bahwa dari sisi penerima apabila menggunakan key list yang berbeda (bukan key yang sama antara pengirim dan penerima) maka key yang digunakan di sisi penerima pesan tidak akan dapat digunakan sebelum key yang sama dikirimkan oleh pengirim

b. Mail Account Listing Pada Mail Client

Mail account yang digunakan adalah mail account dengan engine mail Zimbra. Mail account dengan engine Zimbra menggunakan konfigurasi SMTP IMAP. Adapun dalam penelitian yang dilakukan, untuk pembacaan email dan pengiriman yang mengenkripsi dengan key private yang dibuat menggunakan aplikasi Mozilla thunderbird. Mail account yang ada di list ke dalam mail client Mozilla Thunderbird

c. Key Listing pada Mail Account Zimbra

Hasil Key yang dibuat dalam hasil file extention .asc, di import ke dalam mail client. Key yang diimportkan harus sesuai dengan identitas yang ada saat men-generate key awal Pada tahap ini harus dipastikan bahwa key yang digunkaan oleh pengirim dan penerima adalah sama. Karena penggunaan key yang berbeda maka akan berdampak pada pembacaan email yang diterima dimana email yang terbaca dalam bentuk chiperteks (tersandikan dan tidak terbaca)

d. PGP Activated

Pada tahapan ini, PGP diaktifkan dengan memberikan autorisasi pada teks mail. Bentuk pengaktifan dengan cara mencetak pilihan button enigmail dalam pengiriman. Aktifasi yang dilakukan juga berlaku pada pengiriman file attachment. Dan sign digital modul teraktifkan. Apabila telah diaktifkan maka proses akhir adlaah melakukan pengiriman email

e. Mail Sending

Pengiriman email yang dilakukan adalah dengan mengirimkan teks mail dan file attachment. Pengujian dan analisa dilakukan dengan membandingkan hasil pengirman email oleh sisi penerima email. Dimana untuk pengiriman teks mail dibandingan dengan pembacaan mail teks dengan aplikasi browser standar dan dibandingkan dengan pembacaan teks mail menggunakan aplikasi Mozilla Thunderbird. Untuk file attachment dilakukan dengan menganalisa besar size yang diciptakan dari hasil pengamanan PGP serta mengukur sebera jauh perbedaan yang muncul. Selain itu juga dilakukan penganalisaan terhadap mail header yang ada di kedua penerimaan baik menggunakan standar pembacaan berupa browser default dan aplikasi mail client.

\section{Kajian Pustaka}

a. Mail Server Zimbra

Mail server (juga dikenal sebagai sebuah mail transfer agent atau MTA, mail router atau mailer Internet) adalah sebuah aplikasi yang akan menerima email masuk dari pengguna lokal (orang-orang dalam satu domain) dan jarak jauh pengirim dan meneruskan email keluar untuk pengiriman. Sebuah komputer yang didedikasikan untuk menjalankan aplikasi tersebut juga disebut sebagai mail server [4]. Microsoft Exchange, qmail, Exim dan sendmail adalah lebih umum di antara program-program server mail.

Zimbra adalah sebuah produk groupware yang dibuat oleh Zimbra, Inc yang berlokasi di Palo Alto, California, Amerika Serikat. Pada masa awal- awalnya perusahaan ini di beli oleh Yahoo! tepatnya pada bulan september 2007. Zimbra pada dasarnya sekelas dengan aplikasi Microsoft Exchange Server. Bedanya, Zimbra tersedia dalam 2 edisi, yaitu Open source Edition dan Network Edition. Dewasa ini zimbra merupakan software open source mail server yang mulai banyak digunakan dengan kemudahan instalasi dan 
management. Di masa yang akan datang zimbra dapat menjadi suatu aplikasi mail server yang paling banyak digunakan seperti postfix, sendmail dan qmail. Berikut aplikasi open source yang digunakan Zimbra Collaboration Suite yang sudah merupakan aplikasi standar yang dipakai di dunia industry [5]:

- Jetty, aplikasi server web yang menjalankan aplikasi Zimbra. - Postfix, aplikasi open source MTA (Mail Transfer Agent) yang menjalankan email server Zimbra.

- OpenLDAP, aplikasi open source sebagai Lightweight Directory Accses Protocol (LDAP) yang berguna untuk autentikasi user.

- MySQL, aplikasi database

- Lucane, aplikasi open-source power full text index dan search engine.

- Anti-Virus and anti-spam, aplikasi open source yang terdiri dari : Clamav anti virus scanner yang melindungi file dari serangan virus, SpamAssassin mail filter yang mengidentifikasi adanya Spam dan Amavisd-new sebagai interface antara MTA dengan yang lain.

b. Kriptography

- James/Sieve filtering, membuat filter untuk email

Kriptografi adalah suatu ilmu yang mempelajari bagaimana cara menjaga agar data atau pesan tetap aman saat dikirimkan, dari pengirim ke penerima melalui mekanisme transmisi komunikasi tanpa adanya gangguan dari pihak ketiga. Menurut Bruce Scheiner dalam bukunya "Applied Cryptography", kriptografi adalah ilmu pengetahuan dan seni menjaga pesan tetap aman ( secure).

Prinsip - prinsip yang mendasari kriptografi yakni :

- Confidelity (kerahasiaan) yaitu layanan agar isi pesan yang dikirimkan tetap rahasia dan tidak diketahui oleh pihak lain (kecuali pihak pengirim, pihak penerima / pihak - pihak memiliki ijin). Umumnya hal ini dilakukan dengan cara membuat suatu algoritma matematis yang mampu mengubah data hingga menjadi sulit untuk di baca dan dipahami.

- Data integrity (keutuhan data) yaitu layanan yang mampu mengenali/mendeteksi adanya manipulasi (penghapusan, pengubahan atau penambahan) data yang tidak sah (oleh pihak lain).

- Authentication (keotentikan) yaitu layanan yang berhubungan dengan identifikasi. Baik otentikasi pihak - pihak yang terlibat dalam pengiriman data maupun otentikasi keaslian data/informasi.

- Non - repudiation (anti - penyangkalan) yaitu layanan yang dapat mencegah suatu pihak untuk menyangkal aksi yang dilakukan sebelumnya (menyangkal bahwa pesan tersebut berasal dirinya)

Istilah - istilah yang digunakan dalam bidang kriptografi :

- Plaintext (M) adalah pesan yang hendak dikirimkan (berisi data asli).

- Ciphertext (C) adalah pesan ter-enkrip (tersandi) yang merupakan hasil enkripsi.

- Enkripsi (fungsi E) adalah proses pengubahan plaintextmenjadi ciphertext.

- Dekripsi (fungsi D) adalah kebalikan dari enkripsi yakni mengubah ciphertext menjadi plaintext , sehingga berupa data awal/asli

Kriptografi itu sendiri terdiri dari dua proses utama yakni proses enkripsi dan proses dekripsi. Proses enkripsi mengubah plaintext menjadi ciphertext (dengan menggunakan kunci tertentu) sehingga isi informasi pada pesan tersebut sukar dimengerti

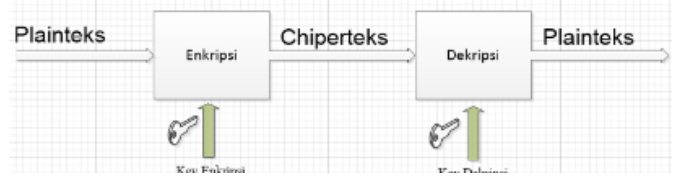

Gambar 2. Alur Enkripsi dan Dekripsi

Dasar matematis yang mendasari proses enkripsi dan dekripsi adalah relasi antara dua himpunan yaitu yang berisi elemen teks terang/plaintext dan yang berisi elemen teks sandi/ciphertext yang ditunjukkan pada matematis berikut :

Enkripsi : 


$$
E(M)=C
$$

Dekripsi :

$$
D(C)=M \text { atau } D(E(M))=M
$$

Enkripsi dan dekripsi merupakan fungsi transformasi antara himpunan-himpunan tersebut. Apabila elemen-elemen teks terang dinotasikan dengan $\mathrm{M}$, elemen-elemen teks sandi dinotasikan dengan $C$, sedang untuk proses enkripsi dinotasikan dengan $E$, dekripsi dengan notasi D. Dalam skenario sistem keamanan lainnya seperti steganografi, sebelum proses pengengkripsian dilakukan, pengirim harus memilih pesan yang sesuai dengan carrier message (contohnya gambar, video, audio, teks) dan pemilihan pesan crutial yang efektif disamping penggunaan password yang kuat (diketahui oleh penerima).

c. Pretty Good Privacy (PGP)

PGP (Pretty Good Privacy) adalah suatu metode program enkripsi informasi yang memiliki tingkat keamanan cukup tinggi bersifat rahasia dengan menggunakan "PrivatePublic Key" sebagai dasar autentifikasinya sehingga jangan sampai dengan mudah diketahui oleh orang lain yang tidak berhak. PGP membuat sebuah session key, dimana sebuah kunci rahasia pada saat itu. Kunci adalah sebuah bilangan acak yang dihasilkan dari gerakan acak dari mouse dan tombol yang anda tekan. Session Key ini berkerja dengan sangat aman, algoritma enkripsi konvesional yang cepat untuk meng-enkrip plaintext. Hasilnya adalah berupah chiper text. Sekali data dienkripsi, lalu session key ini dienkripsi lagi menggunakan kunci publik penerima. session key yang terenkripsi kunci publik key penerima dikirim dengn chipertext ke penerima. Proses deskripsi bekerja sebaliknya, Penerima menerima pesan lalu membuka pesan tersebut dengan kunci privatnya, namun pesan tersebut masih terenkripsi dengan session key. Dengan Menggunakan PGP, penerima mendekrip chipertext yang terenkripsi secara konvensional. Kombinasi dari 2 metode enkripsi menggabungkan kehandalan dari enkripsi kunci publik dengan kecepatan pada enkripsi konvensional. Enkripsi Konvensional kuarang lebih 1000x lebih cepat dari enkripsi kunci publik. Jadi enkripsi kunci publik memberikan sebuah solusi pada distribusi kunci dan masalah transmisi data. Dengan menggunakan keduanya, perfoma dan distribusi kunci dapat ditingkatkan tanpa mengorbankan sesuatu dalam keamanan.

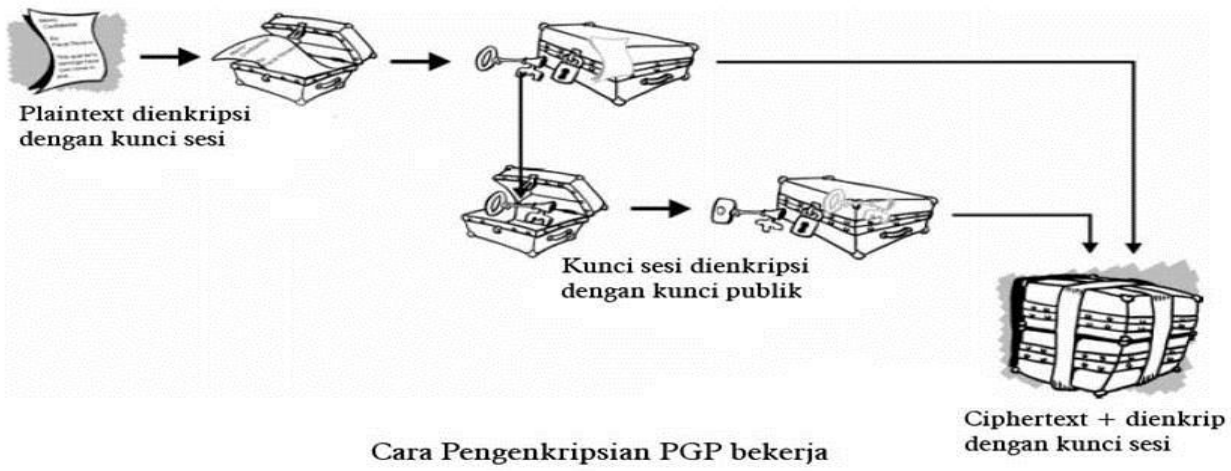

Gambar 3. Alur Kerja PGP

Prinsip kerja dari PGP itu sendiri adalah :

- $\quad$ PGP menggunakan teknik yang disebut Public-key encryption dengan dua kode yang saling berhubungan secara intrinsik, namun tidak mungkin untuk memecahkan satu dan yang lainnya.

- Jika membuat suatu kunci, secara otomatis akan dihasilkan sepasang kunci yaitu public key dan secret key. Pengirim dapat memberikan public key ke manapun tujuan yang diinginkan, melalui telephone, internet, keyserver, dsb. Secret key yang disimpan pada mesin pengirim dan menggunakan messager decipher akan 
dikirimkan ke penerima oleh pengirim di sisi yang lain. Jadi yang akan menggunakan public key (yang hanya dapat didekripsi oleh oleh secret key), mengirimkan messages kepada penerima, dan penerima akan menggunakan secret key untuk membaca pesan dari pengirim.

- $\quad$ PGP menggunakan dua kunci yaitu kunci public (proses enkripsi) dan private (proses deskripsi). Menggunakan dua kuci tersebut dikarenakan adanya conventional crypto, disaat terjadi transfer informasi kunci, suatu secure channel diperlukan

\section{Hasil dan Pembahasan}

Pada penelitian yang dilakukan, sebelum melakukan pengujian berdasarkan metodelogi penelitian yang telah dibahas sebelumnya, maka dilakukan perencanaan dalam bentuk pembuatan rancangan arsitektur penelitian. Rancangan yang dimaksud adalah sebagai berikut.

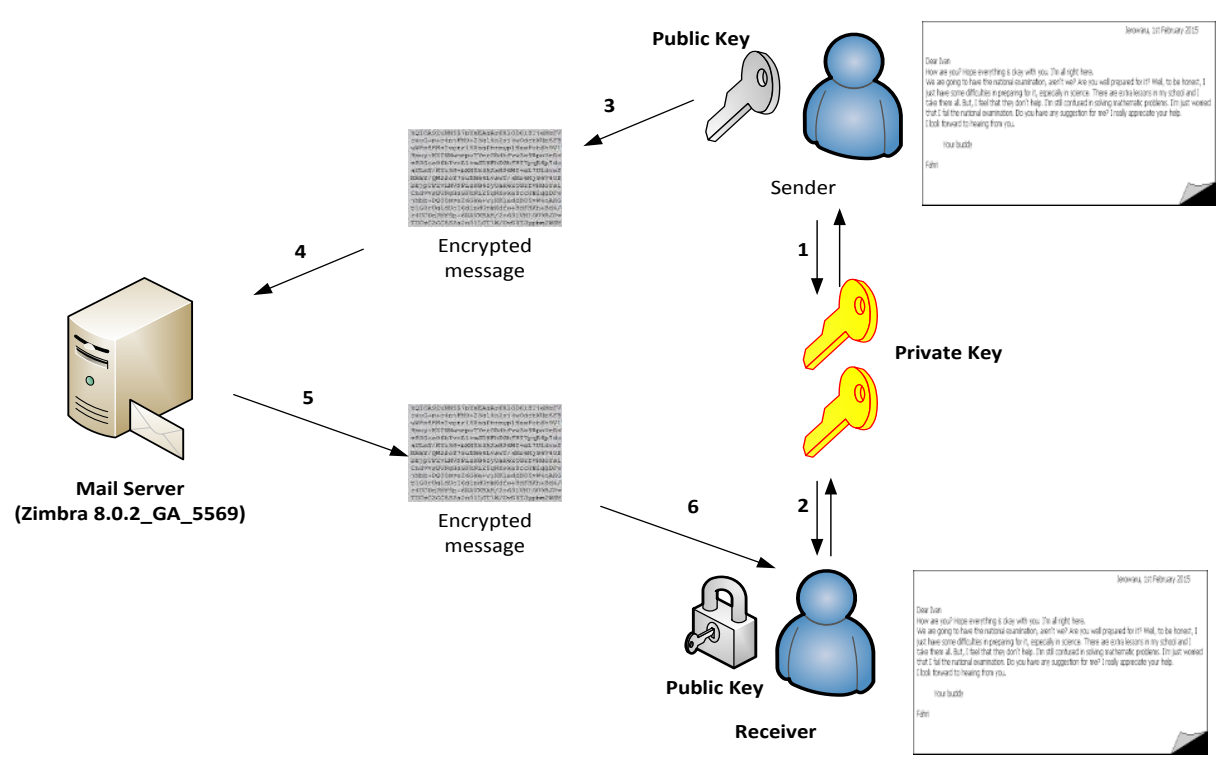

Gambar 4. Rancang Bangun Arsitektur PGP

Seperti yang sudah dibahas sebelumnya bahwa pengamanan komunikasi email menggunakan PGP teknik diawali dengan adanya kepemilikan kunci private. Kunci private ini dimiliki oleh kedua aktor yaitu pengirim email dan penerima email. Kunci ini harus ada sebelum pengiriman email dilakukan (proses 1 dan 2 pada gambar 5). Setelah kunci private dikirimkan oleh kedua aktor, dilakukannya pengiriman pesan oleh pengirim. Pesan yang dikirimkan dienkripsi sebelum dikirimkan ke penerima. Sehingga pesan dikirimkan adalah dalam bentuk chiperteks (pesan tersandikan). Adapun proses penyandian yang dilakukan adalah menggunakan kunci public. Pengiriman dilakukan di atas platform mesin zimbra. Dari sisi penerima, penerima akan menerima dalam bentuk chiperteks. Chiperteks yang diterima akan di dekrip kembali menggunakan kunci private yang telah dimiliki di awal komunikasi. Dengan kepemilikan kunci private, maka pesan dapat ditampilkan kembali. Apabila kunci private yang digunakan untuk mendekrip tidak sama dengan kunci private pengirim, maka pesan tersebut tidak dapat terbaca. Pengujian yang dilakukan dalam penelitian adalah dengan membandingkan mekanisme pengiriman dan penerimaan email antara pengiriman email standard dan pengiriman yang menggunakan teknik PGP. Hasil pengujian pertama adalah membandingkan bentuk PGP yang digambarkan sebagai berikut : 


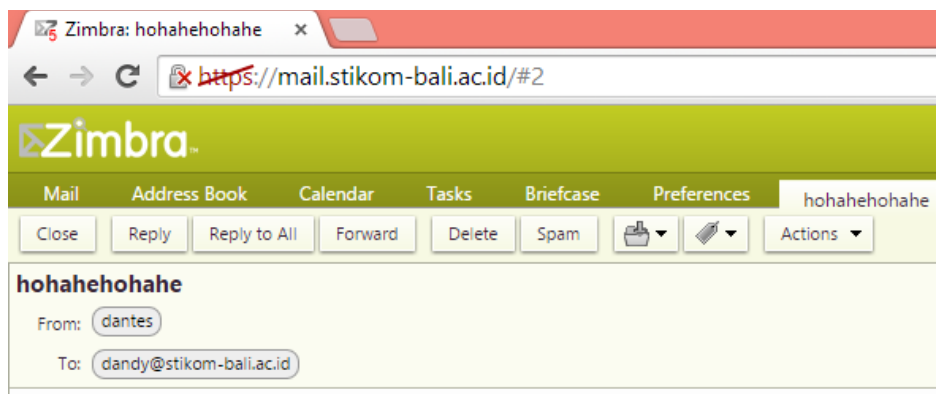

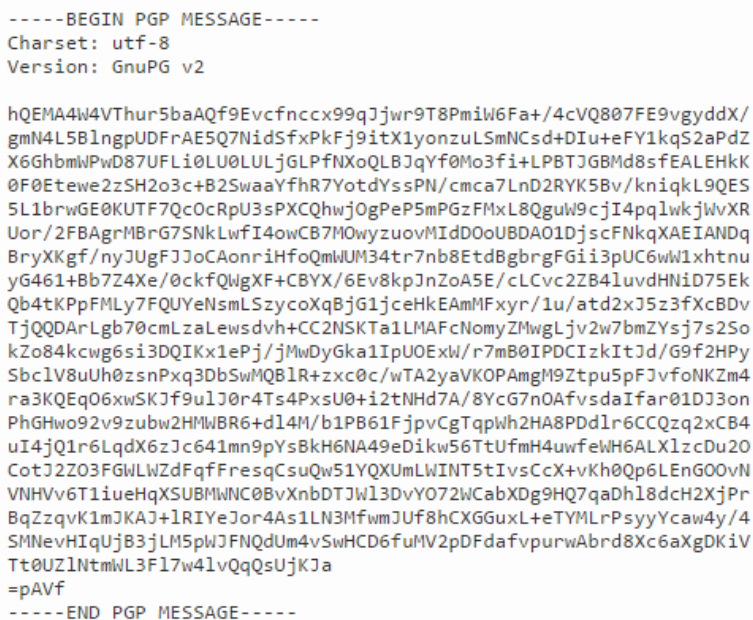

Gambar 5. Hasil PGP

Dari Gambar 5 dapat dilihat bahwa hasil pengamanan dengan PGP merubah teks dalam email menjadi teks yang tidak dapat terbaca atau dalam bentuk sandi yang disebut chiperteks. Pengujian kedua dilakukan dengan membandingkan file attachment pada pengiriman email, Setelah dilakukan pengiriman file attachment dianalisa dari bentuk penerimaan dan perubahan size ukuran file attachment. Hasil penerimaan file PGP dengan browser dan pembandingan ukuran size ditunjukkan pada gambar berikut :

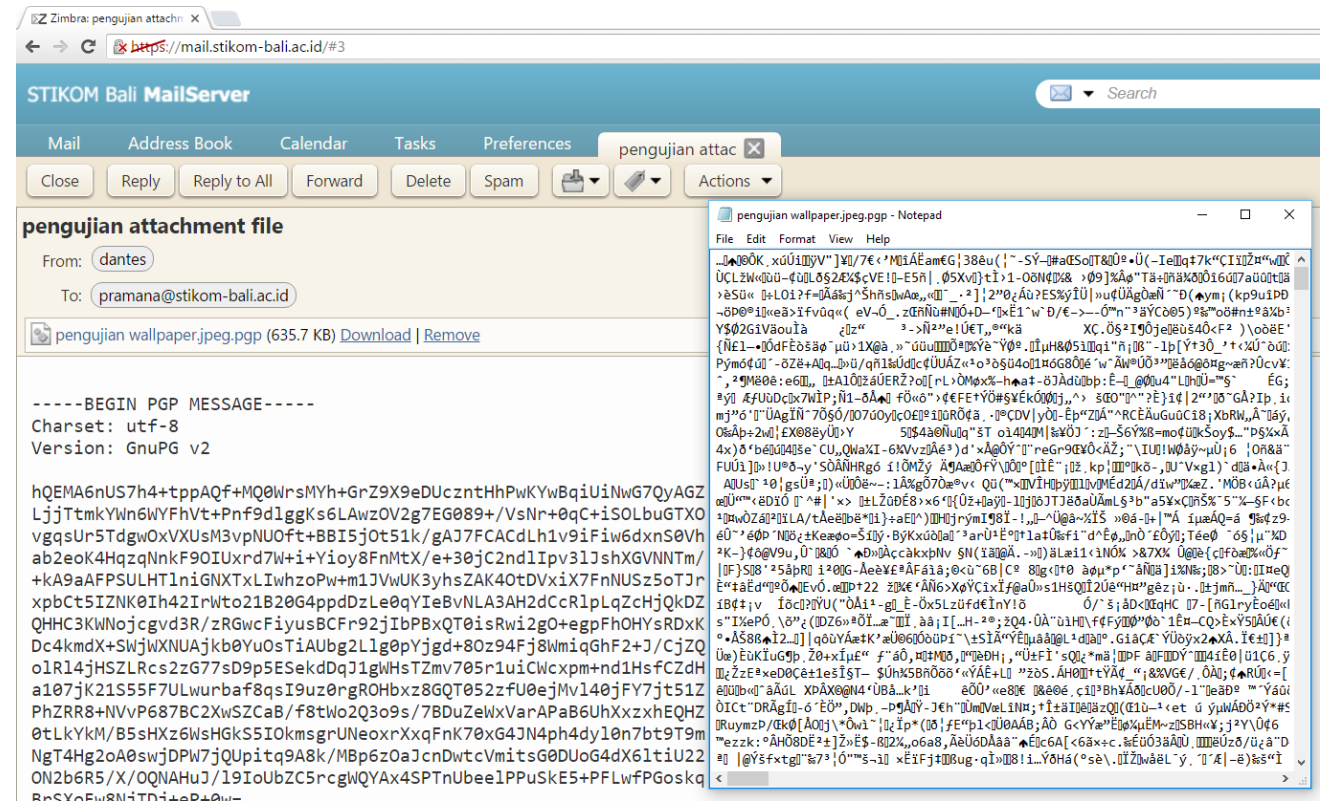

Gambar 6a. Pembacaan mail dengan browser 


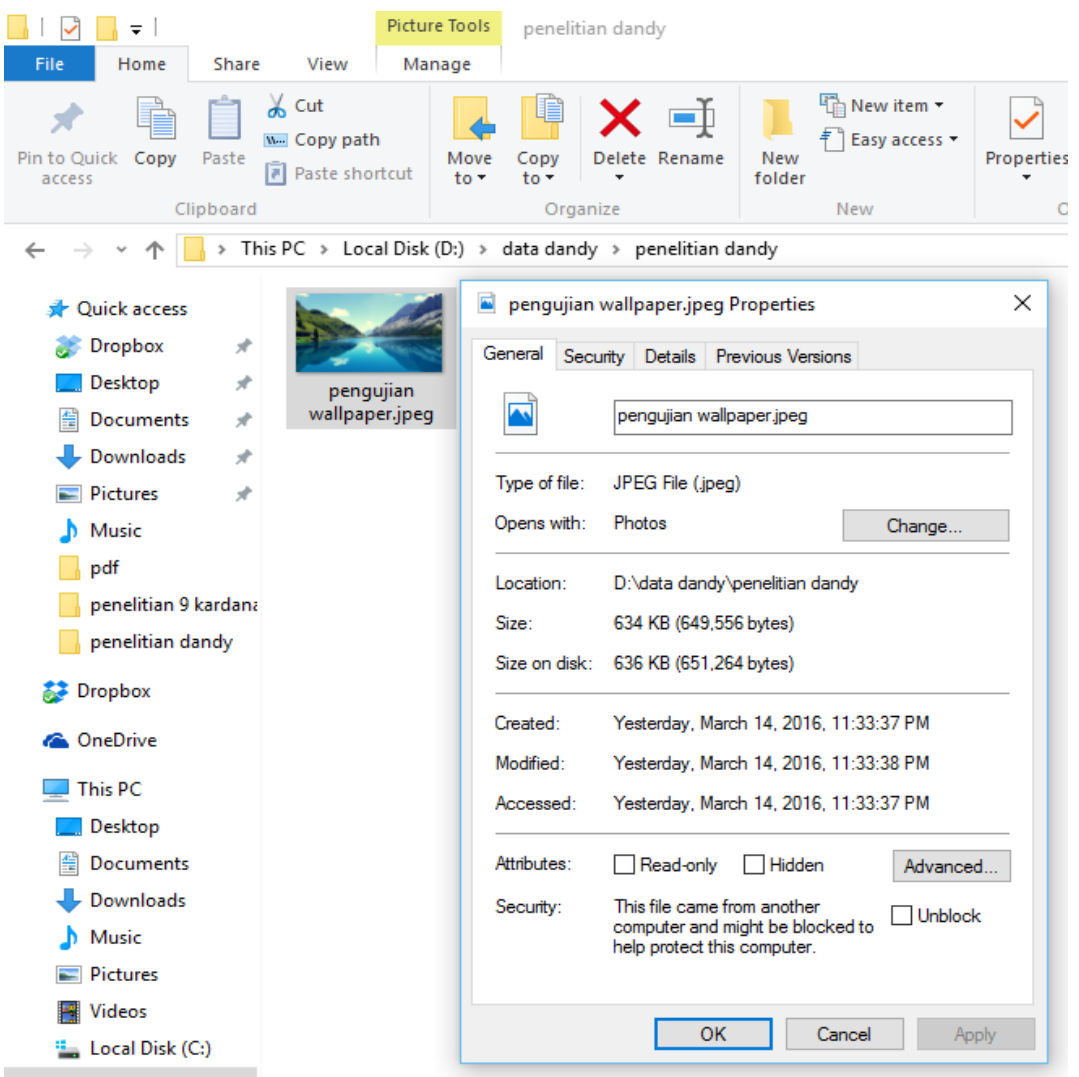

Gambar 7b. Perbandingan file attachment

Hasil pembandingan kompresi data dari pengiriman PGP diambil dari pengujian pengukuran file pengiriman yang dicek berdasarkan nilai hash dan ukuran data (file size). Kemudian dilihat pembanding kompresi dengan PGP sehingga mendapatkan nilai kompresi dari data yang dikirimkan menggunakan PGP. Contoh data ditunjukkan pada tabel berikut :

Tabel 1. Tabel Uji Pembanding Data

\begin{tabular}{|c|c|c|c|c|c|c|c|c|c|c|}
\hline \multirow[t]{3}{*}{ No } & \multirow{3}{*}{$\begin{array}{l}\text { Tipe } \\
\text { File }\end{array}$} & \multicolumn{3}{|c|}{ File Pengirim (file asli) } & \multicolumn{3}{|c|}{ File Penerima tanpa PGP } & \multicolumn{3}{|c|}{ File Penerima dengan PGP } \\
\hline & & \multicolumn{2}{|c|}{ MD5 Hash } & \multirow{2}{*}{$\begin{array}{c}\text { Size } \\
\text { KB }\end{array}$} & \multicolumn{2}{|c|}{ MD5 Hash } & \multirow{2}{*}{$\begin{array}{c}\text { Size } \\
\text { KB }\end{array}$} & \multicolumn{2}{|c|}{ MD5 Hash } & \multirow{2}{*}{$\begin{array}{l}\text { Size } \\
\text { KB }\end{array}$} \\
\hline & & String & File & & String & File & & String & File & \\
\hline 1 & $\mathrm{ppt}$ & $\begin{array}{l}3128 \mathrm{e} 8 \mathrm{da} 7038 \mathrm{f} \\
8 \mathrm{~b} 714 \mathrm{f} 4 \mathrm{db} 398 \mathrm{e} \\
\text { a6b8fb }\end{array}$ & $\begin{array}{l}\text { 3f8d1981b51c4 } \\
\text { c7c7a8c27d55a } \\
58 \mathrm{e} 835\end{array}$ & 1702 & $\begin{array}{l}88 f 7 c 635113 \\
\text { a679ef9584c } \\
96616854\end{array}$ & $\begin{array}{l}\text { 9f7f921397568 } \\
\text { c7b75e5bbcf36 } \\
957897\end{array}$ & 982 & $\begin{array}{l}\text { 3f8d1981b51 } \\
\text { c4c7c7a8c27 } \\
\text { d55a58e835 }\end{array}$ & $\begin{array}{l}\text { 3f8d1981b51c4 } \\
\text { c7c7a8c27d55a } \\
58 \mathrm{e} 835\end{array}$ & 1702 \\
\hline 2 & docx & $\begin{array}{l}\text { a3927eaa04e2a } \\
\text { 74d3ffe87445a99 } \\
5 \mathrm{cb} 52\end{array}$ & $\begin{array}{l}8 f 36188 c 2 d d 1 c \\
\text { bb73cb7ff54d6 } \\
9 b c c 57\end{array}$ & 86 & $\begin{array}{l}\text { 9d1993f57dc } \\
\text { e776cd7e8e2 } \\
03 a 4 f 2 b d 23\end{array}$ & $\begin{array}{l}\text { 1bd177effd726 } \\
9 d 699 \mathrm{cf} 108 \mathrm{e} 79 \\
6 \mathrm{ff} 1 \mathrm{c} 2 \mathrm{f}\end{array}$ & 86.4 & $\begin{array}{l}8 f 36188 \mathrm{c} 2 \mathrm{dd} \\
1 \mathrm{cbb} 73 \mathrm{cb} 7 \mathrm{ff} 7 \\
54 \mathrm{~d} 69 \mathrm{bcc} 57\end{array}$ & $\begin{array}{l}\text { c86f286c1a8ec } \\
\text { b66397e39430 } \\
024 a 64 e\end{array}$ & 86 \\
\hline 3 & $\mathrm{xlsx}$ & $\begin{array}{l}63690 d 572 f 37 c \\
985533307 d 8 b 3 \\
\text { a20bf3 }\end{array}$ & $\begin{array}{l}090 a 9 c c 95004 f \\
\text { cf29784329e89 } \\
582014\end{array}$ & 9.01 & $\begin{array}{l}\text { ad7c37ac72e } \\
7 \text { a661102f60 } \\
887 a 3 a d 0 e b\end{array}$ & $\begin{array}{l}\text { 54e98a32f081a } \\
5 a 1 c d 8039 e 80 \\
78849 d 6\end{array}$ & 9.34 & $\begin{array}{l}32 \mathrm{bc} 31 \mathrm{~b} 83 \mathrm{cc} \\
\text { a4565c2c850 } \\
\text { ee5da68e9a }\end{array}$ & $\begin{array}{l}\text { 090a9cc95004f } \\
\text { cf29784329e89 } \\
582014\end{array}$ & 9.01 \\
\hline 4 & doc & $\begin{array}{l}\text { Oc15271c044c9 } \\
\text { db01c749d60b2 } \\
\text { 9de087 }\end{array}$ & $\begin{array}{l}\text { 8a10678dd0fbe } \\
\text { c0cc68ab60036 } \\
\text { 8daafa }\end{array}$ & 6880 & $\begin{array}{l}\text { 68ca60b635e } \\
\text { d54bc5c304ff } \\
46285 c e 91\end{array}$ & $\begin{array}{l}\text { df05281745a07 } \\
7 a 173 a 61 b 867 \\
393 f 212\end{array}$ & 3914 & $\begin{array}{l}\text { Oeb91f33c8f7 } \\
\text { bdadf0314c5 } \\
761250 d 2 c\end{array}$ & $\begin{array}{l}\text { 8a10678dd0fbe } \\
\text { c0cc68ab60036 } \\
\text { 8daafa }\end{array}$ & 6880 \\
\hline 5 & pdf & $\begin{array}{l}671266150 a 083 \\
\text { ef } 84 c 22 e 80 c e 20 \\
17 d 6 c\end{array}$ & $\begin{array}{l}\text { cd3c6f08d6a70 } \\
829950 \text { ee54fe8 } \\
717095\end{array}$ & 108 & $\begin{array}{l}\text { Obb087ae605 } \\
\text { 113c9149896 } \\
\text { 301defef58 }\end{array}$ & $\begin{array}{l}\text { bc153e8514c68 } \\
\text { febe74660a8d8 } \\
\text { 4ee919 }\end{array}$ & 104 & $\begin{array}{l}\text { 6ae10672d3e } \\
\text { f724d073dea } \\
\text { 63d37b3a41 }\end{array}$ & $\begin{array}{l}\text { cd3c6f08d6a70 } \\
829950 \text { ee54fe8 } \\
717095\end{array}$ & 108 \\
\hline 6 & ipa & $\begin{array}{l}7968 c c f f a 88 c d d \\
\text { aa983ebc24445 } \\
3 \text { 3ffe }\end{array}$ & $\begin{array}{l}29056 a 9 c 6 c 37 f \\
\text { cb196a14f7697 } \\
\text { dc83e8 }\end{array}$ & 14626 & $\begin{array}{l}\text { 771eb3da89f } \\
\text { 17e25a7d0a3 } \\
\text { e85370dc7e }\end{array}$ & $\begin{array}{l}448 b c c a 5 d 0890 \\
\text { d965b938b20c } \\
\text { e5fcfof }\end{array}$ & 14627 & $\begin{array}{l}31 \mathrm{e} 6 \mathrm{c} 2018 \mathrm{c} 7 \\
133 \mathrm{bc} 6 f 849 \mathrm{e} \\
9 \mathrm{afdc} 688 \mathrm{e} 5\end{array}$ & $\begin{array}{l}\text { 29056a9c6c37f } \\
\text { cb196a14f7697 } \\
\text { dc83e8 }\end{array}$ & 14626 \\
\hline 7 & exe & $\begin{array}{l}\text { 13a37135ab04f } \\
\text { 4a7ef6a741b55 } \\
31845 e\end{array}$ & $\begin{array}{l}\text { a15923362 cc66a } \\
42 \text { ebb3376c0c8 } \\
\text { d7c4cd }\end{array}$ & 329 & $\begin{array}{l}\text { b002eff4afbc } \\
\text { b7dc7158aa2 } \\
585 \mathrm{e} 5 \mathrm{e} 108\end{array}$ & $\begin{array}{l}\text { Oaa81822f5bbd } \\
\text { c3e44b9378ebc } \\
\text { ac3b6f }\end{array}$ & 148 & $\begin{array}{l}51 \mathrm{cbd} 3327 \mathrm{e} 9 \\
40 \mathrm{cc} 9 \mathrm{f} 26732 \\
05 \mathrm{eb} 4 a c 425\end{array}$ & $\begin{array}{l}\text { a15923362cc6a } \\
42 \mathrm{ebb} 3376 \mathrm{c0c} 8 \\
\text { d7c4cd }\end{array}$ & 329 \\
\hline 8 & xpi & $\begin{array}{l}\text { 0203eba59b160 } \\
\text { b8b5d5ee8ad2e } \\
\text { 10edf1 }\end{array}$ & $\begin{array}{l}3216 e 114290 a \\
4 b 79 b 3643 c 5 b \\
24 b 7612 f\end{array}$ & 30 & $\begin{array}{l}\text { b6af539c8f6e } \\
\text { ecf7f33b0253 } \\
\text { 4defc1bb }\end{array}$ & $\begin{array}{l}\text { c2c4322553018 } \\
\text { c45ebdd3de7b } \\
\text { 8d97e5b }\end{array}$ & 31 & $\begin{array}{l}\text { ddecb52fa9a } \\
\text { cdecdd5851e } \\
\text { 55e11c12af }\end{array}$ & $\begin{array}{l}3216 e 114290 a \\
4 b 79 b 3643 c 5 b \\
24 b 7612 f\end{array}$ & 30 \\
\hline 9 & apk & $\begin{array}{l}86159 \mathrm{~b} 78 \mathrm{~d} 7 \mathrm{~b} 88 \\
1 \mathrm{~d} 050420 \mathrm{~d} 0 \mathrm{~cd} 2\end{array}$ & $\begin{array}{l}445 \mathrm{e} 7 \mathrm{~b} 45 \mathrm{daffd} \\
56 \mathrm{c} 607 \mathrm{~d} 62560\end{array}$ & 8567 & $\begin{array}{l}\text { 41cea4d5961 } \\
\text { bf8c27bfbd41 }\end{array}$ & $\begin{array}{l}22870062 \mathrm{~d} 618 \\
95761 \mathrm{f} 66 \mathrm{ad} 312\end{array}$ & 8568 & $\begin{array}{l}\text { e89bd0341c1 } \\
\text { 6e3e5e56239 }\end{array}$ & $\begin{array}{l}\text { 445e7b45daffd } \\
56 c 607 d 62560\end{array}$ & 8567 \\
\hline & & 346938 & 0ec0e15 & & c4f101a61 & $15 \mathrm{~d} 1 \mathrm{~cd} 4$ & & $32 \mathrm{~b} 547 \mathrm{c} 112$ & 0ec0e15 & \\
\hline 10 & sisx & $\begin{array}{l}670 f 670 b 55 c 57 \\
4 a 3 f a 09 c 3 f e 8 f b \\
3 c 16 d\end{array}$ & $\begin{array}{l}2 \text { cfe5076bba69 } \\
\text { b8b83b542d9b } \\
\text { b3f58a6 }\end{array}$ & 1856 & $\begin{array}{l}\text { eb60f4ee } 399 \\
\text { 44ba826b38e } \\
\text { 2c66ed8460 }\end{array}$ & $\begin{array}{l}42 \mathrm{fb} 0 \mathrm{~d} 3 \mathrm{~b} 41438 \\
5717 \mathrm{e} 80 \mathrm{af} 40 \mathrm{c} 1 \\
23 \mathrm{cf} 88\end{array}$ & 1857 & $\begin{array}{l}\text { d9493e3c83a } \\
213 d d 3 b 8 a f 8 \\
\text { a27f443f74 }\end{array}$ & $\begin{array}{l}\text { 2cfe5076bba69 } \\
\text { b8b83b542d9b } \\
\text { b3f58a6 }\end{array}$ & 1856 \\
\hline
\end{tabular}




\begin{tabular}{|c|c|c|c|c|c|c|c|c|c|c|}
\hline \multirow[t]{3}{*}{11} & svg & bbb9d21b7b950 & 931eb597b54a & 6 & b820bb614b0 & $07 \mathrm{e} 4178 \mathrm{c} 45 \mathrm{e} 5$ & 3 & d97cd625377 & 931eb597b54a & 6 \\
\hline & & 1735ae04f09c2f & a4846ce852d9 & & 037f75e99e2 & 51766 da36242 & & 199c170a8c6 & a4846ce852d9 & \\
\hline & & df2dc & b6752cec & & 257 aff3fc9 & d1a9e80b & & 81abec716f & b6752cec & \\
\hline \multirow[t]{3}{*}{12} & $\mathrm{bmp}$ & 6baad7b80d313 & $2 \mathrm{bc} 6646 \mathrm{e} 1822$ & 149 & $3 \mathrm{cod} 3 \mathrm{f} 1955 \mathrm{c}$ & 5b13aea99212 & 100 & 69777863ecf & $2 \mathrm{bc} 6646 \mathrm{e} 1822$ & 149 \\
\hline & & $4 c 82 d 73 a 775 f a 7$ & $0759031056 \mathrm{~cd}$ & & af305f213ebf & 98bf6ac6e7a76 & & $8436281 \mathrm{bf22}$ & $0759031056 \mathrm{~cd}$ & \\
\hline & & c98d1 & eb8783de & & $1240 f 2 b b 4$ & $82 \mathrm{c} 1 \mathrm{~d} 9 \mathrm{e}$ & & $9 \mathrm{a} 14 \mathrm{e} 0 \mathrm{~b} 468$ & eb8783de & \\
\hline \multirow[t]{3}{*}{13} & ico & $99 \mathrm{cb} 115 \mathrm{c} 43 \mathrm{dcd}$ & 6892a234406a & 126 & $42199 a 5 c 202$ & b5a0f7728d5df & 75 & b635691a98e & 6892a234406a & 126 \\
\hline & & 3289c5832e062 & 1b5066ffd4704 & & $7 \mathrm{~d} 1 \mathrm{fd} 947597$ & bd7203221836 & & 06494de7cb1 & 1b5066ffd4704 & \\
\hline & & ca6446 & $51039 d 5$ & & $0 e 83 a 0 d 57 c$ & 4e91015 & & f3c3d99712 & $51039 d 5$ & \\
\hline \multirow[t]{3}{*}{14} & jpg & fa8ecc21879ee4 & $3 b 5672336 f 64 f$ & 8 & da00e4a807f & $4168 \mathrm{fdfb} 90 \mathrm{bd} 4$ & 9 & Ofac958e0ec5 & $3 b 5672336 f 64 f$ & 8 \\
\hline & & $128773 d 01 f 525$ & fe295187c4f39 & & b7931643a01 & $2718 a 7872530$ & & c47a68e8c08 & fe295187c4f39 & \\
\hline & & e411d & $4056 \mathrm{dc}$ & & 0893991dbb & e286077 & & b7f9143a8 & $4056 \mathrm{dc}$ & \\
\hline \multirow[t]{3}{*}{15} & png & 092142e9ddcf8 & $4 \mathrm{~d} 8 \mathrm{cc} 8 \mathrm{~b} 6 \mathrm{dc} 066$ & 113 & $7 f 1 e 0 b f e 9 c 7 b$ & $378 f 4 d 1 c 9 c 591$ & 108 & e820e262449 & $4 \mathrm{~d} 8 \mathrm{cc} 8 \mathrm{~b} 6$ & 113 \\
\hline & & 189ac7b8f8a811 & $2 \mathrm{dbbfac} 41 \mathrm{bf} 32$ & & aea612cb614 & $7465521 f 9734 \mathrm{e}$ & & bf783ab32b3 & 2dbbfac41bf32 & \\
\hline & & f9ł35 & $3 b 053 b$ & & $468 \mathrm{fe} 0806$ & $91141 \mathrm{f}$ & & a2fca9e619 & $3 \mathrm{~b} 053 \mathrm{~b}$ & \\
\hline \multirow[t]{3}{*}{16} & aiff & 24ad56758ccd4 & $52 c e 4540 e 93 d$ & 10450 & $463998 \mathrm{a} 6226$ & bdd719f6d0e5e & 7552 & $4577 \mathrm{e} 96 c 57 f$ & 52 ce 4540 e $93 d$ & 10450 \\
\hline & & c5b68c13df2ce3 & $31056 c 9 f 91 c 6 d$ & & $37371 \mathrm{~b} 4 \mathrm{bb} 31$ & a7475f38cfad9 & & $04 c 95002362$ & $31056 c 9 f 91 c 6 d$ & \\
\hline & & $4 a a 2 a$ & e65fa9d & & d917e55f92 & $879 d 39$ & & $90 f e 2808 c 1$ & e65fa9d & \\
\hline \multirow[t]{3}{*}{17} & ogg & $62 \mathrm{dcafb} 3 e e d d 4 f$ & $43 b 2003306 a 9$ & 3166 & d2c008bf894 & 87bae720c1eb & 3161 & $318 f a b b b 59 f$ & $43 \mathrm{~b} 2003306 a 9$ & 3166 \\
\hline & & 5f957ce1bf4787 & 108450aaac471 & & cc0577bb458 & 6a4fbde9171cd & & $36 \mathrm{e} 26 \mathrm{ce} 4501$ & 108450aaac471 & \\
\hline & & 5694 & $d c 54 c 3 d$ & & 66е69e3078 & $68 \mathrm{e} 5619$ & & f7801346c1 & $d c 54 c 3 d$ & \\
\hline \multirow[t]{3}{*}{18} & wav & 84f7082a09c959 & 84f7082a09c95 & 10451 & 2caa549dddd & $5 b 48452 e 9582$ & 7541 & Ofd578ca114 & 84f7082a09c95 & 10451 \\
\hline & & b1374d73ca908 & $9 \mathrm{~b} 1374 d 73 \mathrm{ca9}$ & & $2 f 5 d f 415 b 67$ & 20abde7a5239 & & 7bde7aa7713 & $9 \mathrm{~b} 1374 \mathrm{~d} 73 \mathrm{ca9}$ & \\
\hline & & Oacfd & 080acfd & & d32c43d6ef & be 141340 & & $391 a 0 c 674 e$ & 080acfd & \\
\hline \multirow[t]{3}{*}{19} & flac & b11a2bf636bec & b17c38c8f95d9 & 335 & 1edc408e50c & 9a10821bd960 & 330 & 2e0cc04cfeb6 & b17c38c8f95d9 & 335 \\
\hline & & $8 \mathrm{e} 464 \mathrm{a} 4 \mathrm{~b} 82776$ & b3fc920452721 & & 01d9a5e3e04 & eb9391763550 & & cf397b7089f6 & b3fc920452721 & \\
\hline & & Зае327 & be1352 & & $135206 \mathrm{c} 0 \mathrm{dc}$ & cf36e261 & & e3031494 & be1352 & \\
\hline \multirow[t]{3}{*}{20} & $\mathrm{mp3}$ & 35f5bfa3aea70e & $1 f 4759754 c 62 c$ & 78 & 1744 efc106c & 26374c2aea950 & 46 & $7 \mathrm{~d} 56 \mathrm{bbd} 1 \mathrm{~d} 53$ & $1 f 4759754 c 62 c$ & 78 \\
\hline & & cdc0877d55650 & $5 e 0 a c 6700364 a$ & & $9 \mathrm{~b} 9 \mathrm{~d} 1 \mathrm{ca} 24 \mathrm{cc}$ & $0862 \mathrm{~d} 443 \mathrm{e} 8 \mathrm{bc}$ & & 2ed7bb52bae & $5 e 0 a c 6700364 a$ & \\
\hline & & $56 \mathrm{~b} 1 \mathrm{~b}$ & 77ebc1 & & bf74e17c9c & $934 \mathrm{e} 4 \mathrm{dd}$ & & 0967b397f1 & $77 e b c 1$ & \\
\hline \multirow[t]{3}{*}{21} & avi & d986c1f631417 & 58231153bec6 & 2309 & e190e085870 & 78836a590132 & 2080 & $330 a 48 d d 5 c 9$ & 58231153bec6 & 2309 \\
\hline & & $1 \mathrm{~d} 8445 f 1 f 73 f 5 a$ & ec04f10d27c92 & & 4ae3dcef719 & baf80dafc3cbc5 & & e62f1a36a82 & ec04f10d27c92 & \\
\hline & & 30368 & $1 \mathrm{cf57e1}$ & & $8623 c 9 d 385$ & e90ee7 & & $67 b d c d 4 f 1 c$ & $1 \mathrm{cf57e1}$ & \\
\hline \multirow[t]{3}{*}{22} & flv & f5314b5e94953 & $34534260 d 41 c$ & 1180 & b03b12dd088 & da $7 \mathrm{c} 0 \mathrm{~d} 94 \mathrm{c} 0072$ & 1148 & $96 f 3 c d 3$ beca & $34534260 d 41 c$ & 1180 \\
\hline & & $9 \mathrm{~d} 47 \mathrm{bcba} 22 \mathrm{cad}$ & d44f899163e1e & & $58 f c 9 a 44 a 14$ & $637 c d 338 d 682$ & & $\mathrm{a} 5 \mathrm{~b} 72491 \mathrm{fd} 5$ & d44f899163e1e & \\
\hline & & $33 \mathrm{a} 0 \mathrm{e} 2$ & 08540ad & & e4f5551783 & $6 a 86 c 21$ & & $7 c 5 d 5 d 661 b$ & 08540ad & \\
\hline \multirow[t]{3}{*}{23} & $\mathrm{mpg}$ & ef6cffbc711e8f4 & $05 c 41 \mathrm{f} 69073 \mathrm{ba}$ & 1648 & $2 f 9240725 \mathrm{da}$ & f6ce3aefbc61bf & 1377 & 6acf7baa626 & 05c41f69073ba & 1648 \\
\hline & & b4bf075d14653f & b98617daf04b7 & & $20009 \mathrm{f} 29 \mathrm{ec} 2$ & $3 \mathrm{~b} 4 \mathrm{cc0} 0 \mathrm{aa} 28284$ & & Ob0e36fe348 & b98617daf04b7 & \\
\hline & & $3 \mathrm{~d} 3$ & $60 \mathrm{e} 99 \mathrm{f}$ & & b39114582d & a7034 & & $6 e e 859 c 9 b 3$ & $60 \mathrm{e} 99 \mathrm{f}$ & \\
\hline \multirow[t]{3}{*}{24} & $3 g p$ & $5333 b c 735954 c$ & e44a090d0a30c & 6933 & d0b31bc0413 & 324bf3ec06a9e & 6825 & foddc 5 faOaOa & e44a090d0a30c & 6933 \\
\hline & & $9 b 7162 f f 66 f 1 c 3$ & 7 e6fd97ec3672 & & $93 \mathrm{c} 92 \mathrm{~d} 37652$ & a81f62efdb620 & & 760 bab08237 & $7 e 6 f d 97 e c 3672$ & \\
\hline & & b6c69 & $1 \mathrm{~b} 68 \mathrm{bc}$ & & $7 \mathrm{~d} 2 \mathrm{f} 386 \mathrm{fd} 7$ & $06 a 768$ & & $99609081 \mathrm{f}$ & $1 \mathrm{~b} 68 \mathrm{bc}$ & \\
\hline \multirow[t]{3}{*}{25} & $\mathrm{mp} 4$ & 644190478f6de & adc2d5f563151 & 643 & 97c63fa1957 & $883 a c 3 c b 4 a 542$ & 614 & 7989c199656 & $\operatorname{adc2d5f563151~}$ & 643 \\
\hline & & $9 \mathrm{~b} 3 \mathrm{~d} 4 \mathrm{e} 947 \mathrm{e} 1 \mathrm{~b} 1$ & $624 d 33 e 82684$ & & dd6c4f221e3 & 2cc5eb06a7f97 & & $542 \mathrm{~d} 8 \mathrm{a} 8301 \mathrm{f}$ & $624 d 33 e 82684$ & \\
\hline & & $9 \mathrm{fb} 657$ & b2471db & & $3 a b d 828 \mathrm{e} 16$ & ae8439 & & 196e5dba37 & b2471db & \\
\hline
\end{tabular}

Dari Tabel 1, dapat dilihat bahwa dari sisi penerima memiliki perbedaan ukuran data dari hasil pengiriman PGP. Prosentase yang dihitung adalah dengan membandingkan selisih antara penerimaan dengan key PGP dan tanpa key PGP berbanding file asli penerimaan. Dengan penghitungan sebagai berikut :

$$
\text { Prosentase perubahan }=\frac{\text { Size file Penerima }(\text { dengan key } P G P)-\text { Size file Penerima }(\text { Non PGP })}{\text { Ukuran File Pengirim }}
$$

Hasil prosentase dapat ditunjukkan pada Tabel 2 berikut :

Tabel 2. Hasil Pengukuran Perbandingan

\begin{tabular}{ccccccl}
\hline No & Tipe & File Asli & Tanpa PGP & Dengan PGP & & Perubahan \\
\cline { 3 - 7 } & File & & & & Keterangan \\
\hline $\mathbf{1}$ & File 1 & 1702 & 982 & 1702 & $42.30 \%$ & lebih kecil dari file asli \\
$\mathbf{2}$ & File 2 & 86 & 86.4 & 86 & $-0.47 \%$ & lebih besar dari file asli \\
$\mathbf{3}$ & File 3 & 9.01 & 9.34 & 9.01 & $-3.66 \%$ & lebih besar dari file asli \\
$\mathbf{4}$ & File 4 & 6880 & 3914 & 6880 & $43.11 \%$ & lebih kecil dari file asli \\
$\mathbf{5}$ & File 5 & 108 & 104 & 108 & $3.70 \%$ & lebih kecil dari file asli \\
$\mathbf{6}$ & File 6 & 14626 & 14627 & 14626 & $-0.01 \%$ & lebih besar dari file asli \\
$\mathbf{7}$ & File 7 & 329 & 148 & 329 & $55.02 \%$ & lebih kecil dari file asli \\
$\mathbf{8}$ & File 8 & 30 & 31 & 30 & $-3.33 \%$ & lebih besar dari file asli \\
$\mathbf{9}$ & File 9 & 8567 & 8568 & 8567 & $-0.01 \%$ & lebih besar dari file asli \\
$\mathbf{1 0}$ & File 10 & 1856 & 1857 & 1856 & $-0.05 \%$ & lebih besar dari file asli \\
\hline
\end{tabular}




\begin{tabular}{lccccrl}
\hline $\mathbf{1 1}$ & File 11 & 6 & 3 & 6 & $50.00 \%$ & lebih kecil dari file asli \\
$\mathbf{1 2}$ & File 12 & 149 & 100 & 149 & $32.89 \%$ & lebih kecil dari file asli \\
$\mathbf{1 3}$ & File 13 & 126 & 75 & 126 & $40.48 \%$ & lebih kecil dari file asli \\
$\mathbf{1 4}$ & File 14 & 8 & 9 & 8 & $-12.50 \%$ & lebih besar dari file asli \\
$\mathbf{1 5}$ & File 15 & 113 & 108 & 113 & $4.42 \%$ & lebih kecil dari file asli \\
$\mathbf{1 6}$ & File 16 & 10450 & 7552 & 10450 & $27.73 \%$ & lebih kecil dari file asli \\
$\mathbf{1 7}$ & File 17 & 3166 & 3161 & 3166 & $0.16 \%$ & lebih kecil dari file asli \\
$\mathbf{1 8}$ & File 18 & 10451 & 7541 & 10451 & $27.84 \%$ & lebih kecil dari file asli \\
$\mathbf{1 9}$ & File 19 & 335 & 330 & 335 & $1.49 \%$ & lebih kecil dari file asli \\
$\mathbf{2 0}$ & File 20 & 78 & 46 & 78 & $41.03 \%$ & lebih kecil dari file asli \\
$\mathbf{2 1}$ & File 21 & 2309 & 2080 & 2309 & $9.92 \%$ & lebih kecil dari file asli \\
$\mathbf{2 2}$ & File 22 & 1180 & 1148 & 1180 & $2.71 \%$ & lebih kecil dari file asli \\
$\mathbf{2 3}$ & File 23 & 1648 & 1377 & 1648 & $16.44 \%$ & lebih kecil dari file asli \\
$\mathbf{2 4}$ & File 24 & 6933 & 6825 & 6933 & $1.56 \%$ & lebih kecil dari file asli \\
$\mathbf{2 5}$ & File 25 & 643 & 614 & 643 & $4.51 \%$ & lebih kecil dari file asli \\
\hline
\end{tabular}

Dari Tabel 2 dapat dilihat bahwa terdapat perubahan ukuran data. Perubahan terlihat saat penerima email menerima file attachment. Untuk hasil prosentase positif menunjukkan bahwa file yang diterima untuk penerimaan key PGP adalah lebih besar dibandingkan dengan tanpa key PGP yang artinya bahwa penerimaan email dengan PGP sesuai dengan file asli pengiriman dan memiliki resiko rendah terhadap kesalahan pengiriman data (dibuktikan bahwa penerimaan dengan PGP memiliki nilai hash yang sama dengan file asli). Sedangkan untuk nilai prosentasi negative ( - ) memiliki arti bahwa penerimaan email dengan PGP tidak sesuai dengan file asli pengiriman dan memiliki resiko lebih tinggi terhadap kesalahan pengiriman data. Dari Tabel 2 dapat digambarkan graph penerimaan email prosentasi pembanding ukuran data PGP sebagai berikut :

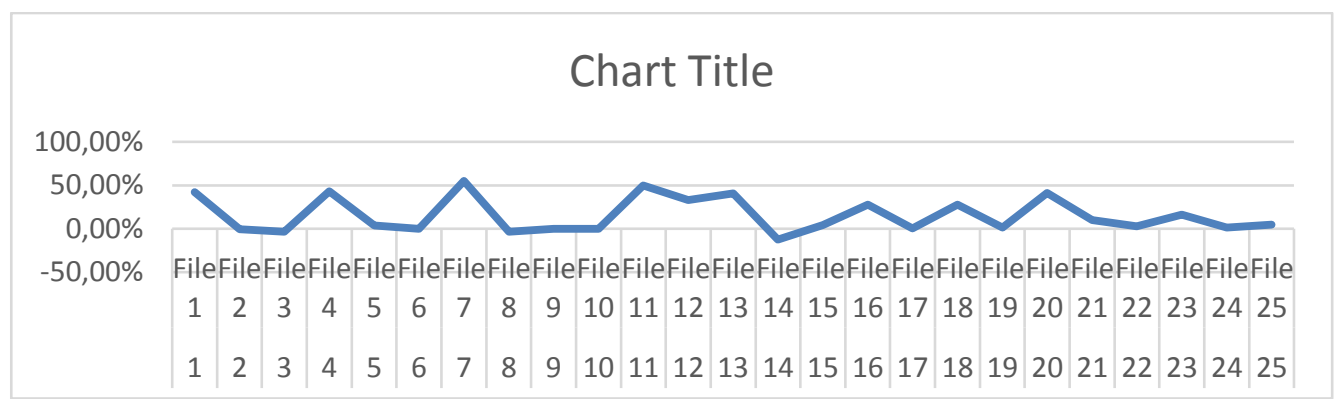

Gambar 8. Graph Prosentasi Pembanding key PGP

Untuk mengetahui rata - rata perubahan file dilakukan penghitungan rerata sebagai berikut :

$$
\begin{aligned}
& \mathrm{x}=\frac{\mathrm{X}(\mathrm{X} 2 \mathrm{i}+\mathrm{X} 3+\ldots \ldots+\mathrm{X} n}{n} \\
& \mathrm{x}=\frac{1}{n} \sum_{i=1}^{n} x 1
\end{aligned}
$$

Dengan pengujian 100 data maka di dapat data stabilitas kompresi terhadap penggunaan key PGP adalah sebesar $15.41 \%$ yang artinya adalah penerimaan email tanpa penggunaan key PGP menunjukkan resiko keruasakan data lebih besar dibandingkan menggunakan key PGP yang seharusnya sama apabila dibandingkan dengan file asli pengirim. Pengujian berikutnya adalah 
dilakukan dengan menganalisa header email antara mail yang dikirimkan dengan menggunakan teknik PGP dan tanpa PGP.

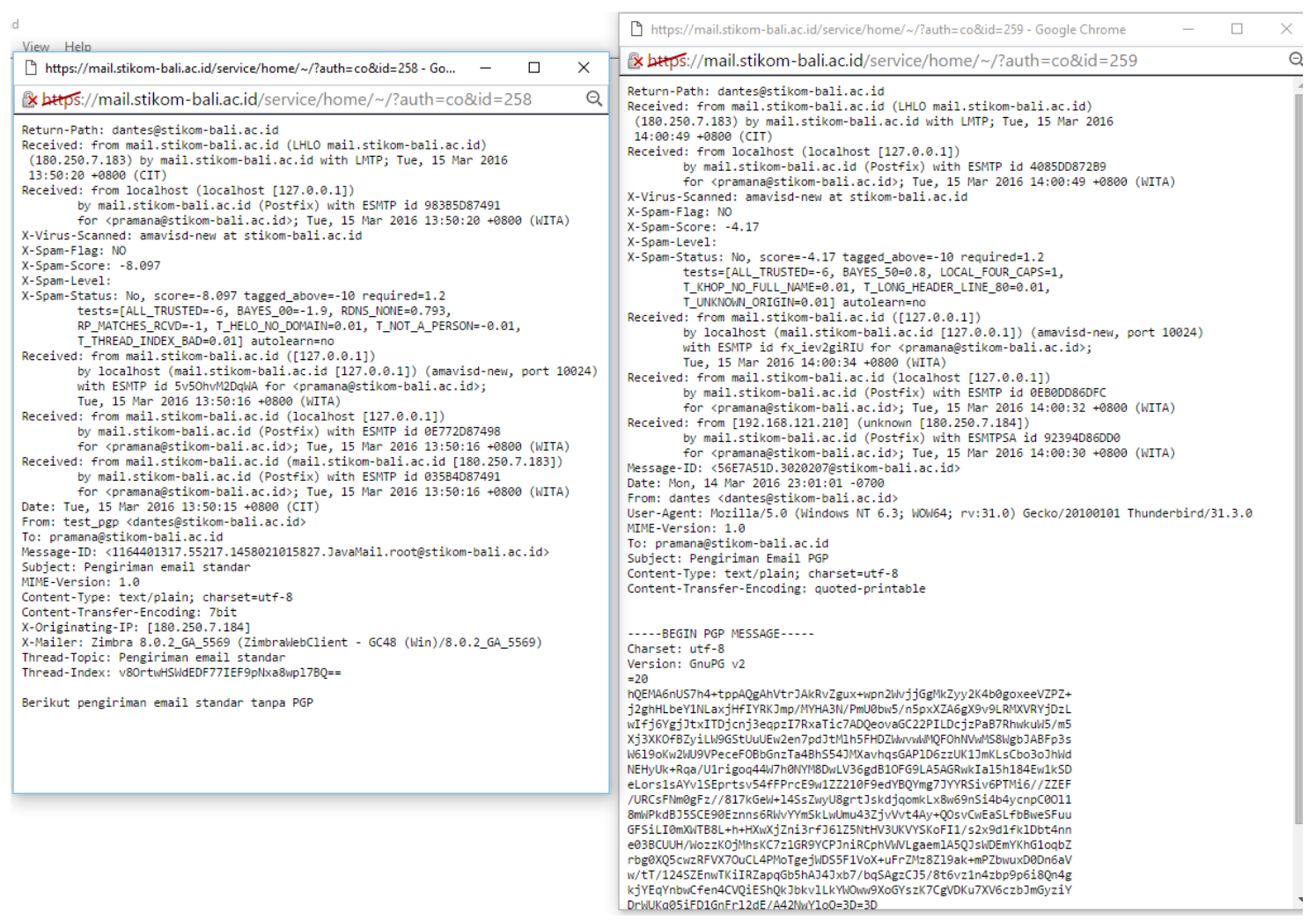

Gambar 9. Perbandingan Mail Header

Dari Gambar 7 dapat dijelaskan yang terlihat bahwa email yang menggunakan PGP memiliki informasi penggunaan User_agent (garis line hitam) yang menjelaskan penggunaan mail client Mozilla Thunderbird. Informasi Message ID pengiriman juga memiliki perbedaan dimana apabila email yang tanpa menggunakan PGP memberikan informasi detail posfix message detail, sedangkan mail yang menggunakan PGP tidak detail. Hal ini dikarenakan menggunakan aplikasi mail client Mozilla Thunderbird. Informasi teknik encoding yang ditampilkan (blok berwarna kuning) terhadap mail yang menggunakan PGP mengartikan bahwa hasil enkripsi tercetak, sedangkan tanpa PGP hanya menggunakan encoding standar pengiriman 7 bit (default mail server STIKOM)

\section{Kesimpulan}

Berdasarkan Penelitian yang dilakukan, dapat disimpulkan bahwa pengamanan menggunakan teknik PGP mampu mengamankan komunikasi email. Pihak yang tidak berkepentingan dapat saja mencuri dan mengetahui user mail account dan password, namun tidak dapat membaca isi dari email karena telah terenkripsi. Hasil analisa juga menunjukkan bahwa terdapat perbedaan size ukuran dari file attachment yang menggunakan pengamanan PGP, dimana size file menjadi lebih besar yang disebabkan adanya proses enkripsi dengan kunci private. Disisi lain, terlihat perbedaan mail header dimana pengamanan PGP memberikan identitas enkripsi dibandingkan mail yang tanpa PGP. Namun analisa mail header juga menunjukkan kurangnya detail informasi mail posfix pada pengamanan dengan teknik PGP.

Sebagai bahan pengembangan pada penelitian berikutnya, dapat dikembangkan penganalisaan terhadap uji coba key generate dari PGP untuk melihat ketahanan terhadap keamanan key PGP dan pengaruh header file dari hasil enkripsi dengan pengujian pada mail engine lainnya 


\section{Daftar Pustaka}

[1] A. Silberschatz, P. B. Galvin, and G. Gagne, Operating System Concepts Essentials. 2011.

[2] A. Dumka, R. Tomar, J. C. Patni, and A. Anand, "Taxonomy of Email Security Protocol," Int. J. Innov. Res. Comput. Commun. Eng., 2014.

[3] A. Bacard, The Computer Privacy Handbook. Peachpit Press, 1995.

[4] M. Os et al., "ZIMBRA Mail Server With Ubuntu 8 . 04."

[5] E. Zaida and Rusmanto, Panduan Praktis Membangun Server Email Enterprise dengan Zimbra. Jakarta: Dian Rakyat, 2010. 